\title{
Energetic consequences of a major change in habitat use: endangered Brent Geese Branta bernicla hrota losing their main food resource
}

\author{
KEVIN KUHLMANN CLAUSEN, ${ }^{1 *}$ PREBEN CLAUSEN,${ }^{1}$ CASPER CÆESAR FÆLLED ${ }^{1}$ \& \\ KIM NØRGAARD MOURITSEN² \\ ${ }^{1}$ Department of Bioscience, Aarhus University, Grenåvej 14, 8410 Rønde, Denmark \\ ${ }^{2}$ Department of Bioscience, Aarhus University, Ole Worms Allé 1, 8000 Aarhus, Denmark
}

\begin{abstract}
Coastal seagrasses are declining at increasing rates worldwide, forcing herbivores previously reliant on these habitats to abandon them in search of alternative ways to fulfil their daily energy budgets. After two decades of declining seagrass abundance in Mariager Fjord, Denmark, the Svalbard breeding population of Light-bellied Brent Geese Branta bernicla hrota has experienced substantial changes in habitat use at this traditional autumn staging area. Declines in seagrasses have caused birds to depend increasingly on Sea Lettuce Ulva lactuca in recent years, and forced birds into terrestrial habitats such as saltmarsh and winter wheat. In contrast to those birds exploiting aquatic habitats, birds relying on these new habitats showed higher energy expenditure and failed to balance their energy budget. Eelgrass (Zostera) was energetically superior to other food resources, with marine Ulva being second best. Predicted body mass development under two different scenarios indicate that present habitat use resulted in a midwinter body mass around $122 \mathrm{~g}$ lower than just 20 years ago, equivalent to $c .9 .4 \%$ of Brent Goose body weight. Even after controlling for inter-annual differences in thermoregulatory costs, the effect of changes in habitat use translated into a body mass reduction of $c .56 \mathrm{~g}$, which could adversely affect survival and future reproduction. Flyway-wide declines in Zostera abundance and further reductions in traditional habitats due to climate change give cause to reassess projected population trends and consequent management implications for the East Atlantic flyway population of Light-bellied Brent Geese.
\end{abstract}

Keywords: eelgrass, energetics, foraging, habitat loss, saltmarsh, Zostera.

Habitat deterioration caused by humans is a major threat to many biomes. During the past century, submerged aquatic vegetation communities (e.g. eelgrass Zostera and ditch-grass Ruppia beds), intertidal mudflats and coastal saltmarshes are among those habitats that have been subject to the largest distributional reductions. Reclamation, disease and increased eutrophication have adversely affected many seagrass communities (Short \& Neckles 1999, Waycott et al. 2009), whereas changes in land use and management have reduced saltmarsh habitats, whose availability may decline further as a consequence of climate change-induced rises in sea level (Adam 2002, Hughes 2004). Seagrass beds

${ }^{*}$ Corresponding author.

Email: kc@dmu.dk and intertidal mudflats are very productive and home to a diverse community of small fish and invertebrates, and seagrasses themselves are consumed by some mammals, many fish and herbivorous waterbirds (Valentine \& Duffy 2006). Saltmarshes function as important breeding and staging habitats for a variety of waterbirds, many of which forage on seagrass beds, mudflats and saltmarshes in alternation (Evans et al. 1984). Reductions in the distribution and abundance of the preferred seagrasses have obliged herbivorous swans, geese and ducks to exploit secondary habitats (intertidal algae and saltmarshes) (Tubbs \& Tubbs 1982) as well as completely new habitats such as pastures and fields of cereal, sugar beet and oil-seed rape (Brunckhorst 1996, Chisholm \& Spray 2002, Nolet et al. 2002). This has prompted 
a need to understand the energetic and behavioural consequences of these alternative foraging strategies (e.g. Prop \& Black 1998) because herbivorous waterbirds rely on accumulation of body stores in spring to fuel long-distance flights to the breeding areas and initiate subsequent breeding, and in autumn to enhance winter survival (Drent et al. 1978/79, Ebbinge \& Spaans 1995, Tinkler et al. 2009).

Herbivorous birds with short gut retention times and limited digestive capabilities exploit high-quality food at high rates of food consumption (Demment \& Van Soest 1985, Prop \& Vulink 1992). They prefer to feed on plants with low cellulose and hemicellulose and high protein and soluble carbohydrate contents, and exhibit a daily schedule of almost uninterrupted feeding (Prop \& Vulink 1992, Stock \& Hofeditz 1997). Consequently, even small changes in food availability, quality or behavioural constraint can accumulate into considerable energetic and fitness consequences on a seasonal timescale (Stock \& Hofeditz 1997).

We aim to assess the consequences of observed habitat shifts resulting from loss of seagrass habitat over the past 20 years on a critically small population of Brent Geese. Such knowledge is necessary for effective management of staging areas for Brent Geese and other herbivores and is a prerequisite for effective conservation measures. By comparing historical (1989) and present (2009) habitat use of Brent Geese we aim (1) to describe the magnitude of change in habitat use, (2) to model energetic consequences of this change in habitat use and (3) to describe changes in winter condition and body mass development. This permits an evaluation of ecological constraints associated with the loss of a major food resource, and a reassessment of likely future population trajectories and management implications for a small and vulnerable population.

\section{METHODS}

\section{Study species, population and range}

The Brent Goose Branta bernicla has a strong preference for feeding on eelgrass Zostera (Einarsen 1965, Ganter 2000). The East Atlantic population of Light-bellied Brent Geese B. b. hrota has one of the smallest populations of any goose (Clausen et al. 1999), numbering only 7600 individuals in 2008/ 2009, and it is one of only two goose populations with unfavourable conservation status in the Western Palaearctic (Fox et al. 2010). During the non-breeding period the majority of birds reside at a few well-defined staging areas in Denmark and at Lindisfarne in northeast England (Clausen et al. 1999, Denny et al. 2004), where submerged and intertidal vegetation are the most important food sources (Clausen \& Percival 1998).

\section{Study area}

The study was carried out in Mariager Fjord, Denmark $\left(56.70^{\circ} \mathrm{N}, 10.22^{\circ} \mathrm{E}\right)$, the most important autumn and winter staging area for the population since the 1950s (Salmonsen 1958, Clausen et al. 1998). Fieldwork was carried out during 1989 and 2009 in and around the shallow inlet, on a range of Brent Goose habitats including seagrass beds (Zostera marina, Ruppia maritima and Ruppia cirrhosa), shallow bays with Sea Lettuce, saltmarshes dominated by Common Saltmarsh Grass Puccinellia maritima, and agricultural fields of wheat Triticum sp. Mariager Fjord is designated as a Ramsar site and a Special Protection Area under the EU Birds Directive for Light-bellied Brent Geese, and as a Special Area of Conservation for saltmarsh, intertidal mudflats and large, shallow inlets and bays under the EU Habitats Directive (Naturstyrelsen 2011). Despite these protection measures, the distributions of Ruppia and Zostera in Mariager Fjord declined by 95 and 31\%, respectively, between 1989 and 2009 (Fælled 2011), followed by a decline in Brent Goose numbers (Fælled 2011). Birds are now restricted to a few coastal Zostera beds outside the fjord, which are situated in deeper water and can sustain bird numbers only for a limited period of time. The only accessible macrophytes that remain are a population of Sea Lettuce fluctuating greatly in both spatial distribution and temporal availability throughout the staging period.

\section{Goose counts and habitat exploitation}

Habitat use was based on monthly total counts in Mariager Fjord during September to December 1989 and 2009. Bird numbers and geographical locations were marked on field maps (scale 1:25 000), and flocks were assigned to one of the five habitats Zostera, Ruppia, Ulva, Puccinellia (saltmarsh) or Triticum (winter wheat), as mapped by vegetation surveys carried out in the preceding summers. 
In 1989, Mariager Fjord still had a relatively large community of macrophytes (Fog 1972, Clausen \& Percival 1998) and we assume habitat use in that year to indicate traditional levels. In the energetic comparison of the two years, birds counted on Ruppia during 1989 were included in the Zostera group. Today Ruppia has completely disappeared from the fjord (Fælled 2011) and energetic analyses of Brent Geese using this habitat in 2009 were unattainable. However, both Ward (1983) and Clausen (1991) found that Brent Geese preferred Ruppia slightly to Zostera, and it is therefore assumed that energetic returns for birds feeding on Ruppia are at least as good as for Zostera.

\section{Time budgets}

Detailed time budgets were compiled in all habitats by scan sampling with 10-min intervals (Altmann 1974) from September to December 2009. Birds were assigned to one of nine different activity categories (Table 1) and data were analysed based on daily averages of time spent in each of these activities. Data are presented as overall means (mean-of-means), describing the average percentages of time across all observation days in the four habitats. Data were arcsine-square roottransformed before analysis, and assumptions of normality carefully evaluated.

Table 1. Behavioural activity categories used in time-budget studies, and estimated energetic costs for Brent Geese, expressed as multiples of basal metabolic rate (BMR)

\begin{tabular}{lcl}
\hline Activity & $\begin{array}{c}\text { BMR- } \\
\text { multipliers }\end{array}$ & \multicolumn{1}{c}{ Reference } \\
\hline Foraging & 1.7 & Stahl et al. (2001) \\
Roosting & 1.6 & Stahl et al. (2001) \\
Swimming & 2.2 & Wooley and Owen \\
& & (1978) \\
Flying & 13.4 & Ladin et al. (2011) \\
Preening & 1.8 & Stahl et al. (2001) \\
Aggression & 1.9 & Stahl et al. (2001) \\
Walking & 1.9 & Stahl et al. (2001) \\
Alert & 1.7 & Stahl et al. (2001) \\
Drinking & 1.5 & Persson (1989) \\
Nightly activities & 1.7 & Wooley and Owen \\
& & (1978) \\
\hline
\end{tabular}

*Night time behaviour is not fully clarified and is described here as a composite measure of the activities roosting and swimming.

\section{Daily metabolizable energy}

Daily metabolizable energy (DME) was quantified from data on the daily excretion rate (DE), daily ingestion rate (DI, both in $\mathrm{g}$ organic dry weight per day), and gross energy content of food $\left(\mathrm{GE}_{f}\right)$ and excreta $\left(\mathrm{GE}_{e}\right)$, measured as $\mathrm{kJ} / \mathrm{g}$ dry organic weight (Stock \& Hofeditz 1997):

$$
\mathrm{DME}_{[\mathrm{kJ} / \text { day }]}=\left(\mathrm{DI} \times \mathrm{GE}_{f}\right)-\left(\mathrm{DE} \times \mathrm{GE}_{e}\right) .
$$

Daily excretion was assessed from dropping mass (dried to constant weight at $80{ }^{\circ} \mathrm{C}$ for $24 \mathrm{~h}$ ) and defecation rates in the exploited habitats, following the hourly block method (Bédard \& Gauthier 1986). As the cloacal region is out of sight when geese forage in water, dropping rates for birds feeding on Ulva and Zostera were assessed from observations of birds immediately after leaving the water. Whenever possible, collection of droppings from aquatic areas was made at foraging sites exposed at low water levels, but on some occasions they were collected from terrestrial areas following aquatic feeding bouts, carefully selecting fresh droppings. Ash content was determined by burning the droppings in a muffle furnace at $400{ }^{\circ} \mathrm{C}$ for $2 \mathrm{~h}$. Daily excretion is defined as:

$$
\mathrm{DE}_{[g \text { org DW/day }]}=(\mathrm{DR} \times T+25) \times m_{e}
$$

where DR gives the defecation rate per minute, $T$ the daily time available for excretion (in minutes) and $m_{e}$ the average ash-free mass (g) of one dropping in the given habitat. The addition of a constant of 25 is an estimate of faecal output during the night (Stock \& Hofeditz 1997). Because geese arrive on their morning feeding grounds with empty stomachs, there is no excretion until newly ingested food has passed through the digestive system. Thus, daily excretion time corresponds to local day length (sunrise to sunset) minus a throughput time of 90 min (Owen 1975).

Daily ingestion was quantified indirectly through knowledge of daily excretion and apparent digestibility of food sources (Stock \& Hofeditz 1997):

$$
\mathrm{DI}_{[\mathrm{g} \text { org DW/day }]}=\mathrm{DE} /(1-\mathrm{AD})
$$

where DE is daily excretion measured as above, and $\mathrm{AD}$ the apparent digestibility of ingested food items. Measures of gross energy in food and excreta are obtained from previous studies 
Table 2. Digestibility and energy content of food sources for Light-bellied Brent Geese in Mariager Fjord

\begin{tabular}{lcccl}
\hline Habitat & AD & $\begin{array}{c}\text { Energy in } \\
\text { food }(\mathrm{kJ} / \mathrm{g})\end{array}$ & $\begin{array}{c}\text { Energy in } \\
\text { excreta } \\
(\mathrm{kJ} / \mathrm{g})\end{array}$ & References \\
\hline Triticum $^{\star}$ & 0.45 & 21.10 & 18.61 & $\begin{array}{l}\text { Brunckhorst } \\
(1996)\end{array}$ \\
Puccinellia $^{\dagger}$ & 0.31 & 22.26 & 20.39 & $\begin{array}{l}\text { Drent } \text { et al. } \\
(1978 / 79)\end{array}$ \\
Ulva $^{\ddagger}$ & 0.34 & 19.63 & 15.28 & $\begin{array}{l}\text { Drent } \text { et al. } \\
(1978 / 79) \\
\text { Zostera }\end{array}$ \\
Zot al. \\
(1978/79)
\end{tabular}

${ }^{*}$ As there are no studies of Brent Geese on wheat so far, presented values are from studies on Wigeon Anas penelope, which is similar in both size and feeding habit.

tOther plants are occasionally eaten on saltmarsh, but Puccinellia is by far the most frequent within this area ( $P$. Clausen unpubl data).

${ }^{\ddagger}$ From studies on the closely related Enteromorpha.

(Table 2). When modelling the development in DME throughout autumn, the contribution from the four habitats Zostera/Ruppia, Ulva, Puccinellia and Triticum was weighted according to average habitat use on a monthly basis.

\section{Daily energy expenditure}

Daily energy expenditure (DEE) is expressed as the sum of habitat-specific active metabolic rates and energy expenses associated with thermoregulation under fluctuating ambient temperatures:

$$
\mathrm{DEE}_{[\mathrm{kJ} / \mathrm{day}]}=\Sigma\left(\mathrm{BMR} \times x_{i} \times p_{i}\right)+\mathrm{C}_{t}
$$

where BMR is the basal metabolic rate in $\mathrm{kJ} /$ day (cf. Lasiewski \& Dawson 1967), $x_{i}$ the energetic cost of activity $i$ expressed as multiples of BMR, $p_{i}$ the proportion of time per day spent engaging in activity $i$, and $\mathrm{C}_{t}$ the thermoregulatory cost in $\mathrm{kJ} /$ day. Stock and Hofeditz (1997), Stahl et al. (2001) and Ladin et al. (2011) studied Brent Geese using this approach, and the BMR-multipliers applied in this study are adopted from their work (Table 1).

To quantify thermoregulatory costs $\left(C_{t}\right)$, we used the $+6{ }^{\circ} \mathrm{C}$ lower critical temperature (LCT) for Brent Geese found by Irving et al. (1955), and assumed an energy loss of $1.272 \mathrm{~kJ} / \mathrm{h} /{ }^{\circ} \mathrm{C}$ whenever temperature falls below LCT (Lefebvre \& Raveling 1967, based on Lesser Canada Goose Branta canadensis parvipes with a mass of 1400 g). Previous studies of thermoregulation in waterbirds have found that because of the air-trapping capacities of abdominal down and feathers, very little additional heat is lost from the isolated belly of surface-floating waterfowl to the surrounding water (Stephenson \& Andrews 1997, Bakken et al. 2006, Van Sant \& Bakken 2006). Consequently, most of the extra thermoregulatory costs associated with aquatic feeding represent heat lost from the legs and feet. Kilgore and Schmidt-Nielsen (1975) showed that for Mallards Anas platyrhynchos this additional heat loss is insignificant at ambient temperatures above $0{ }^{\circ} \mathrm{C}$, probably as a consequence of effective counter-current exchange in the limbs. Because Brent Geese are high-Arctic birds likely to be adapted to cold conditions, we assume that this is also true of our study population. As water temperatures below $0{ }^{\circ} \mathrm{C}$ cause the brackish inlet of Mariager Fjord to freeze over, conditions triggering important habitat-specific differences in thermoregulation are never met in our study area. As a consequence, we considered likely differences in thermoregulatory costs between terrestrial and aquatic feeding to be negligible.

The expression of daily $C_{t}$ was estimated from local temperature data acquired from Hald and Foulum, 14 and $32 \mathrm{~km}$ southwest of Mariager Fjord (source: the Danish Meteorological Institute):

$$
\mathrm{C}_{t[\mathrm{~kJ} / \mathrm{day}]}=1.272 \times N \times \Delta t
$$

where $N$ is the number of hours with temperatures below Brent Goose LCT, and $\Delta t$ the average number of degrees below LCT within these hours. Daytime activity patterns are based on habitat-specific time budgets, while the hours of darkness are covered by nocturnal activities (cf. Table 1). Like DME, modelled DEE is weighted according to average monthly habitat use.

\section{Energy balance and body mass development}

Determination of DME and DEE allows for a joint expression of energy balance $(\Delta E$, Stock \& Hofeditz 1997):

$$
\Delta E_{[\mathrm{kJ} / \mathrm{day}]}=\mathrm{DME}-\mathrm{DEE} .
$$

Depending on the sign of $\Delta E$, body mass development can be expressed in terms of the weight 
gained or lost on a daily basis. Assuming an energetic investment of $26 \mathrm{~kJ} / \mathrm{g}$ mass change (Stock \& Hofeditz 1997), the daily change in body mass is estimated as:

$$
\Delta \text { Weight }_{[\mathrm{g} / \mathrm{day}]}=\Delta E / 26 .
$$

To investigate potential fitness-related consequences of Brent Goose habitat change in Mariager Fjord, we modelled expected seasonal body mass trends from habitat use in 1989 and 2009. Change in body weight is modelled from an initial mass of $1305 \mathrm{~g}$ (average weight in early autumn for juvenile and adult birds, Fog 1967). To emphasize the influence of habitat changes and clarify the significance of climate-induced differences between the two scenarios, data for 1989 were modelled using both 1989 and 2009 weather data.

\section{RESULTS}

\section{Habitat use}

During the study period the number of Brent Geese present in the area ranged between 762 and 3048 individuals (mean $=1962$ birds in total counts) in 1989, and 725 and 2271 individuals (mean $=1360$ birds) in 2009. Habitat exploitation changed significantly across months both in 1989 $\left(\chi^{2}=1237.94, \mathrm{df}=6, P<0.0005\right)$ and in 2009 $\left(\chi^{2}=3252.48, \mathrm{df}=9, P<0.0005\right)$ (Fig. 1).

In 1989, Zostera and Ruppia accounted for the majority of Brent Goose habitat use, averaging 62\% of total monthly counts, and birds feeding on Ulva made up roughly $22 \%$. Birds feeding on Puccinellia on saltmarsh accounted for around 7\% during the period September to November, but rose sharply to $44 \%$ in December. This increase occurred simultaneously with a drop in the exploitation of the two fjord habitats, perhaps as a consequence of heavy grazing and winter die-offs in these areas. Agricultural land was not used at all in 1989.

In September 2009, most birds (82\%) fed on the remaining coastal areas with obtainable Zostera. In October the fraction of birds in this habitat fell to $21 \%$, and the Geese exploited secondary habitats such as Puccinellia saltmarsh and Ulva beds. In November, most birds were feeding on Ulva (68\%), and the first Brent Geese were seen feeding on wheat. By December, exploitation of both wheat (24\%) and saltmarsh (34\%) peaked, whereas the use of Ulva had halved and Zostera
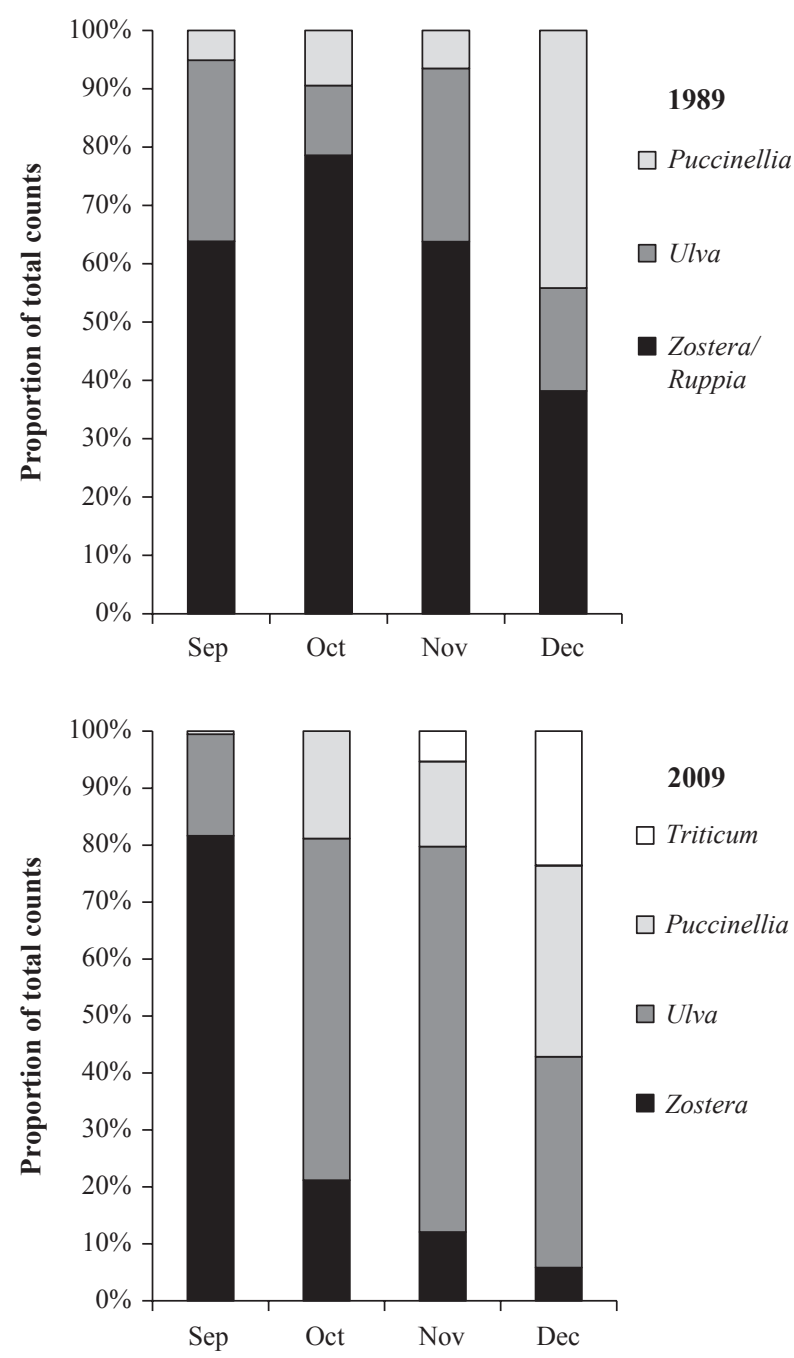

Figure 1. Monthly habitat use in 1989 (top) and 2009 (bottom) among Brent Geese in Mariager Fjord (proportion of total counts).

dropped to under 6\%. Brent Goose habitat use had thus undergone substantial changes within a period of 20 years (month-by-month comparisons, September-December: $\chi^{2}>148.05, \mathrm{df}=2-3, P<$ 0.0005).

\section{Time budgets}

Time budgets revealed clear differences in activity patterns between habitats (Table 3). Brent Geese on winter wheat and saltmarsh spent considerably more time flying, being more aggressive and alert than birds in Zostera and Ulva habitats. Furthermore, the proportions of time spent flying and being alert were significantly higher on agricultural 
Table 3. Mean percentages of time ( + se) that Brent Geese spent engaged in different activities around Mariager Fjord during autumn 2009 in the habitats Triticum, Puccinellia, Zostera and Ulva. $n=$ number of observation days. Different letters indicate significant differences in the behavioural activities between habitats (ANOvA and subsequent Tukey's HSD, $P<0.05$ )

\begin{tabular}{lccrr}
\hline Activity & Triticum $(n=5)$ & Puccinellia $(n=5)$ & Ulva $(n=10)$ & Zostera $(n=13)$ \\
\hline Feeding & $75.5(3.1) \mathrm{A}$ & $77.0(3.5) \mathrm{A}$ & $71.2(6.4) \mathrm{A}$ & $65.0(5.7) \mathrm{A}$ \\
Roosting & $0.8(0.2) \mathrm{A}$ & $1.8(0.7) \mathrm{A}$ & $16.2(4.2) \mathrm{B}$ & $23.1(4.4) \mathrm{B}$ \\
Swimming & $0.0(0.0) \mathrm{A}$ & $3.0(1.9) \mathrm{AB}$ & $7.7(3.3) \mathrm{B}$ & $6.3(1.0) \mathrm{B}$ \\
Flying & $8.8(2.0) \mathrm{A}$ & $3.8(1.0) \mathrm{B}$ & $0.6(0.4) \mathrm{C}$ & $0.8(0.3) \mathrm{C}$ \\
Preening & $2.4(0.2) \mathrm{A}$ & $4.2(1.4) \mathrm{A}$ & $2.4(0.6) \mathrm{A}$ & $3.9(0.8) \mathrm{A}$ \\
Aggression & $4.1(0.7) \mathrm{A}$ & $3.6(0.6) \mathrm{A}$ & $0.6(0.5) \mathrm{B}$ & $0.1(0.1) \mathrm{B}$ \\
Walking & $3.1(0.6) \mathrm{A}$ & $4.1(0.6) \mathrm{A}$ & $0.9(0.8) \mathrm{B}$ & $0.7(0.2) \mathrm{B}$ \\
Alert & $5.2(1.5) \mathrm{A}$ & $2.1(0.5) \mathrm{B}$ & $0.0(0.0) \mathrm{C}$ & $0.0(0.0) \mathrm{C}$ \\
Drinking & $0.2(0.1) \mathrm{AB}$ & $0.4(0.2) \mathrm{A}$ & $0.4(0.3) \mathrm{A}$ & $0.0(0.0) \mathrm{B}$ \\
\hline
\end{tabular}

land than on saltmarsh. In contrast, time spent roosting was significantly higher in both aquatic habitats than in terrestrial ones. The differences in proportions of time spent swimming and walking are a natural consequence of the different habitat types, and when the proportions of swimming and walking are pooled, all habitat-specific differences are non-significant (one-way ANOVA, $F=1.0265$, $\mathrm{df}=3, P=0.3953$ ).

\section{Energy budgets}

Both defecation rate and dropping weight were highest on saltmarsh and lowest in agricultural areas, with aquatic habitats in between (Table 4). Ash content in individual droppings was significantly higher on agricultural land than in the remaining habitats (one-way ANOVA and subsequent Tukey's HSD, $F=4.4598$, $\mathrm{df}=3, P=0.0136$ ) but with no differences between the remaining three $(F=0.1967, \mathrm{df}=2, P=0.8231)$. This might be explained by the relatively sparse vegetation in a newly sprouted winter cereal field, where ingestion of soil particles may be inevitable.

Table 4. Defecation rates and excrement weights from autumn 2009. Sample sizes for defecation rates indicate the number of hourly blocks (cf. Bédard \& Gauthier 1986)

\begin{tabular}{lrrr}
\hline Habitat & $\begin{array}{c}\text { Defecation } \\
\text { rate }(n / \mathrm{h})\end{array}$ & $\begin{array}{c}\text { Excrement } \\
\text { weight (g dry } \\
\text { organic mass) }\end{array}$ & $\begin{array}{c}\text { Ash content } \\
(\% \text { of dry } \\
\text { weight })\end{array}$ \\
\hline Triticum & $9.19(n=2)$ & $0.5077(n=10)$ & $37.3(n=10)$ \\
Puccinellia & $13.99(n=2)$ & $0.5819(n=14)$ & $18.6(n=14)$ \\
Zostera & $12.98(n=2)$ & $0.5326(n=14)$ & $18.6(n=14)$ \\
Ulva & $12.01(n=2)$ & $0.5153(n=14)$ & $21.5(n=14)$ \\
\hline
\end{tabular}

The modelled daily costs associated with thermoregulation around Mariager Fjord predict that for both years the energetic expenses related to $\mathrm{C}_{\mathrm{t}}$ can be accommodated during early autumn. In 1989, November was relatively cold with increased thermoregulatory costs, whereas December was energetically inexpensive. In contrast, November 2009 was comparatively mild, but the onset of an exceptionally cold winter in midDecember implied a rapid increase in thermoregulatory costs in this year (Fig. 2).

The calculated energy budget is illustrated as the habitat-specific average DME and DEE in the period 15 September to 31 December 2009 (Fig. 3). The highest energetic returns are found for birds feeding on Zostera, where DME exceeds DEE over the season. DME is highest for birds feeding on Triticum, but their total energy balance is negative due to elevated DEE in this habitat. Birds feeding on Ulva have low DEE, but the limited DME from this food source prevents it from being a high-quality habitat. When translated into average daily weight gain (Fig. 3), Zostera appears to be of particular importance to Brent Geese in terms of energetic favourability. With an estimated mean weight change from 15 September to 31 December of $2.54 \mathrm{~g} /$ day, the potential of this habitat greatly exceeds the other habitats. The second best energetic situation was for birds foraging on Ulva, which had a near neutral energy balance when extrapolated over the season, and an average weight loss of $0.11 \mathrm{~g} /$ day. Both terrestrial habitats were energetically expensive and if Geese were to forage exclusively on either Puccinellia or Triticum, the average weight change during autumn would be negative and involve losses of 0.90 and $2.81 \mathrm{~g} /$ day, respectively. 


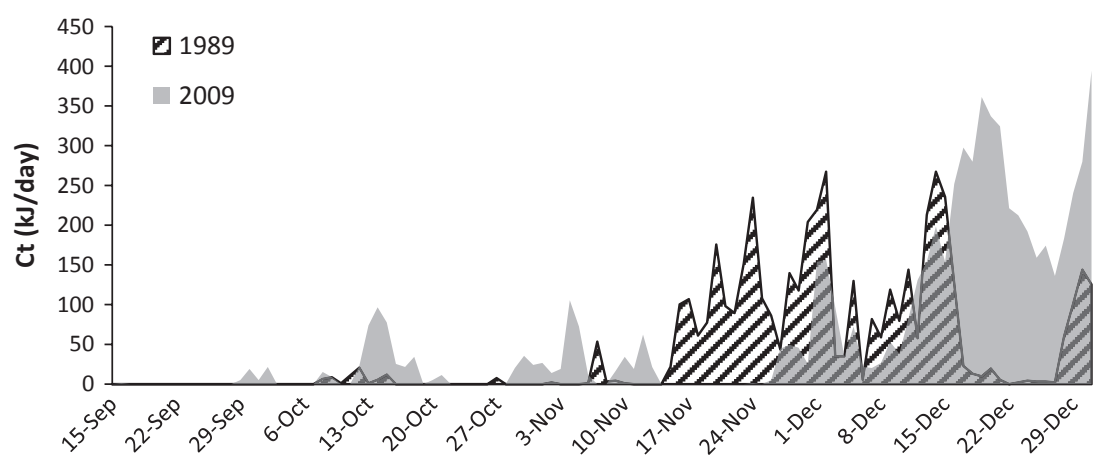

Figure 2. Calculated daily costs of thermoregulation (kJ/day) for Brent Geese in Mariager Fjord, September-December 1989 and 2009.
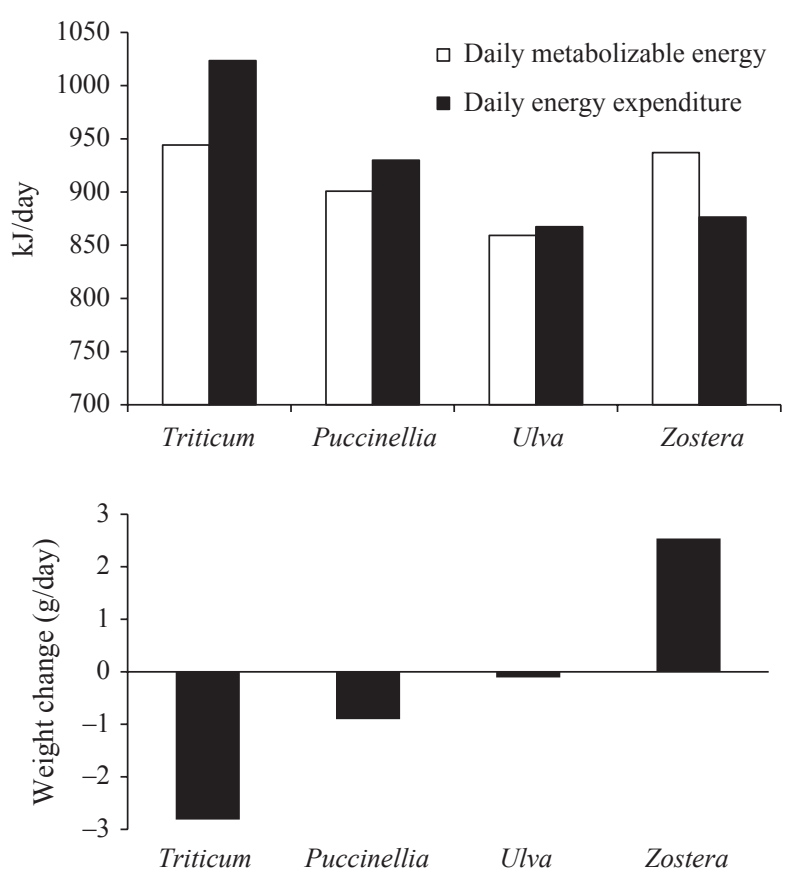

Figure 3. Average daily metabolizable energy (DME) and daily energy expenditure (DEE) in $\mathrm{kJ} /$ day (upper), and resulting habitat-specific average daily weight change ( $g /$ day) (lower) for Brent Geese in September-December 2009, assuming a single-habitat exploitation throughout autumn.

\section{Energy balance and body mass development}

The calculated Brent Goose energy balances in 1989 and 2009 enabled us to quantify the energetic effects of recent changes in habitat exploitation. Brent Goose energy balance was positive under both scenarios in September-October, but $\Delta E$ was considerably higher in 1989 compared with 2009, and remained positive longer into autumn (Fig. 4a). Only during November did the 2009 energy balance exceed that in 1989 due to differences in weather-induced thermoregulatory costs. December brought a major drop in $\Delta E$ in 2009, corresponding with both changes in habitat use and the first cold period of the 2009-2010 winter. The 1989 energy balance was therefore consistently higher during this period, although still negative. Figure 4(b) shows the comparison between 1989 and 2009 with both models based on 2009 weather data, so that differences are attributable only to differences in habitat exploitation. This indicates that changes in habitat exploitation in October and November in 2009 with respect to 1989 resulted in a less favourable energy balance for Brent Geese. In both September and December, the energy balance is virtually identical from this comparison.

When the estimated differences in energy balance are expressed in terms of potential body mass changes, our model indicated that birds in 2009 had generally lower body mass than their 1989 counterparts. The average Brent Goose staging in Mariager Fjord during 2009 was predicted to be approximately $122 \mathrm{~g}$ lighter in late December than a corresponding individual 20 years ago (Fig. 4c), equivalent to a drop of c. $9.4 \%$ in body mass. After taking into account differences in weather between years, this predicts a reduction of $56 \mathrm{~g}$ (equivalent to $c .4 .3 \%$ of body mass) due specifically to habitat change (Fig. $4 \mathrm{~d}$ ).

\section{DISCUSSION}

We have demonstrated a substantial change in habitat use around Mariager Fjord between two 

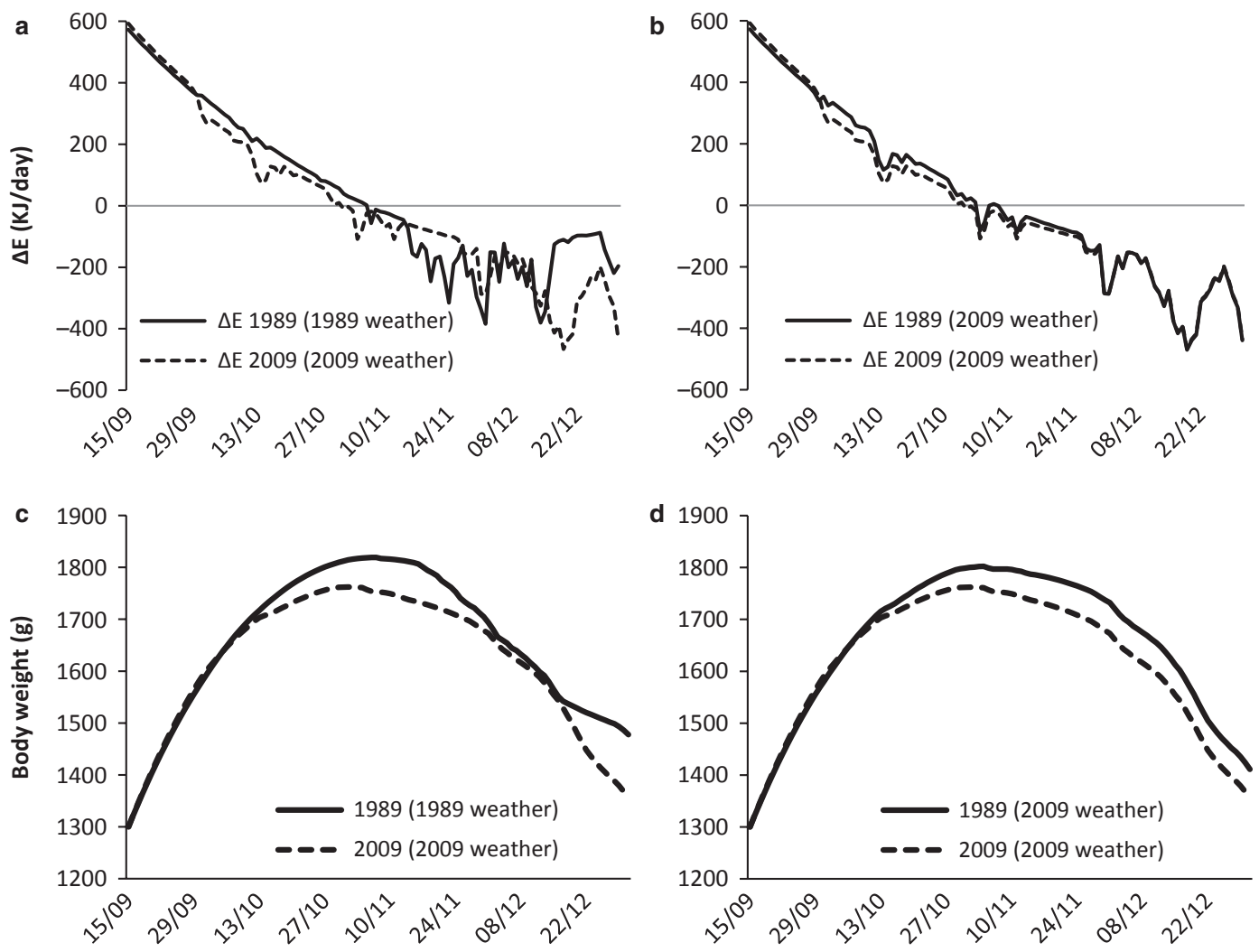

Figure 4. Modelled development in Brent Goose energy balance (upper) and predicted body mass (lower) based on the 1989 and 2009 scenarios. Models in (a) and (c) are based on actual temperature in the two scenarios, whereas (b) and (d) compare a hypothetical situation with equal costs of thermoregulation (2009 data), implying that any divergences are attributable only to differences in habitat exploitation.

winters 20 years apart, over which time Geese left their estuarine habitat and switched to terrestrial areas in response to eutrophication-induced reductions of submerged vegetation and reduced saltmarsh management (Clausen \& Percival 1998, Fælled 2011). Similar changes have also occurred in the three other major autumn staging areas (the Danish Wadden Sea, Lindisfarne, Nibe and Gjøl Bredninger; Clausen \& Percival 1998, Clausen et al. 2009) and Brent Geese have switched partly to saltmarsh and agricultural feeding in these areas too (Denny et al. 2004). On arrival in 2009, Geese clustered together in the few remaining Zostera beds outside Mariager Fjord, which were largely abandoned after 2 weeks. Most Geese were then dependent on Ulva beds and saltmarsh as their main feeding grounds, supplemented by a growing importance of winter-sown cereals on agricultural land - a new and only recently recognized food source for this subspecies. The initial preference for Zostera and the energetic returns associated with this habitat indicate that Geese move on to Ulva, Puccinellia and agricultural land because of energetic necessity, and that habitat use conforms well to the theory of optimal foraging, in which birds behave as fitness-maximizing individuals optimizing their rate of energy intake (Pyke et al. 1977, Kamil et al. 1987). Tubbs and Tubbs (1982) also found that Brent Geese preferred feeding on Zostera whenever available, moved on to Enteromorpha- and Ulva-dominated areas when Zostera became depleted, and only as a last resort to terrestrial habitats. Clausen and Percival (1998), Ganter (2000) and Inger et al. (2008) also emphasize Zostera and other marine resources as the most favourable food source for Brent Geese.

Habitat-specific activities showed similarities between wheat and Puccinellia on the one hand, and Zostera and Ulva on the other, indicating that differences in Brent Goose behaviour are determined by the dichotomy between terrestrial and aquatic foraging habitats. Birds on land appeared 
wary and insecure, resulting in a behaviour in which intensive feeding bouts are separated by flight, aggression and vigilance. Birds in aquatic habitats displayed high frequencies of roosting activities and longer regular feeding periods.

Behaviours observed in this study confirm the 'busy herbivore' lifestyle described by Owen et al. (1992) and Stahl et al. (2001), in which birds forage for the vast majority of the day. Reports of geese feeding for less time derive from studies in which time budget methods distinguish between ingestion and searching for food (e.g. Ladin et al. 2011).

Differences between energy budgets in different habitats are mostly attributable to the elevated energetic cost associated with vigilant behaviour and high frequencies of flying in terrestrial habitats. Vulnerability to terrestrial predators and human disturbance in the winter staging areas are probably partly responsible for this difference and, as Brent Geese are one of the most marine species of goose (Einarsen 1965, Ganter 2000, Ward et al. 2005), the transition to a more terrestrial lifestyle might be a significant challenge. In western Europe, Dark-Bellied Brent Geese B. b. bernicla have a more terrestrial lifestyle, foraging mainly on saltmarshes and pastures (Rowcliffe et al. 1995, Spaans \& Postma 2001) and, in time, Light-Bellied Brent Geese may habituate to a similar pattern of habitat exploitation. For now, however, the elevated energy expenditure associated with these habitats render them clearly secondary to preferred aquatic habitats.

The disappearance of Zostera and Ruppia in Mariager Fjord makes Ulva the best available habitat to foraging Geese for most of the autumn. The abundance and distribution of Ulva in Mariager Fjord has remained relatively unchanged between 1989 and 2009 (Fælled 2011), and while the spread of Ulva may be an indirect contributory cause of loss of Zostera (Zaldivar et al. 2009), this food source is now essential to Brent Geese in the area. Similarly, saltmarsh is now the best terrestrial alternative to marine foraging habitats. Moreover, the negative average weight change found in this study is only representative of autumn energetic demand when days are shortening and Puccinellia energy content is decreasing (Mathers \& Montgomery 1997). As the significance of saltmarsh in spring is well established for this population (Clausen 1998, Clausen et al. 1999), this habitat is now of high importance throughout the wintering cycle.
The potential fitness consequences of habitat change are illustrated by modelled body mass trends. During early autumn, birds put on substantial body mass under both 1989 and 2009 scenarios, foraging mainly on seagrasses in aquatic habitats. This post-breeding build-up of body reserves is considered essential to winter survival because birds return from the breeding grounds with depleted energy stores (e.g. Butler et al. 1998). From October onwards, the poorer body mass trends in 2009 results in a predicted reduction in body mass of $56 \mathrm{~g}$ relative to 1989 habitat conditions after controlling for weather variation. The seasonal pattern of autumn body mass change found here is consistent with findings in other studies of Brent Geese (Ebbinge 1989, Tinkler et al. 2009) and seems to rely on the joint effects of declining available food, shortening day length and environmental conditions. Both DMEs and DEEs estimated in this study conform to previous results (Drent et al. 1978/79, Stock \& Hofeditz 1997), and estimated daily change in body mass is well within observed values (Ebbinge 1989). In late December, the model indicates weights are around $1350-1470 \mathrm{~g}$.

Lane and Hassall (1996) describe nocturnal feeding among Brent Geese that could potentially compensate for habitat loss. However, no observations of nocturnal feeding have been made in the Danish staging area, which might be related to the fact that feeding at night is usually restricted to aquatic habitats (Tinkler et al. 2009) and these are now rare in Mariager Fjord. Night feeding was therefore only possible under 1989 conditions, thereby exacerbating differences in energy accumulations between the 1989 and 2009 scenarios.

Linking autumn weights to their demographic consequences is a complex task. It is well established that Brent Geese have higher mortality in colder winters (Clausen et al. 1998, 2001) and the predicted drop in body mass (and therefore energy stores) might reduce winter survival. Moreover, it is known that juvenile recruitment is tightly coupled to pre-breeding body mass among females (Ebbinge 1989, Ebbinge \& Spaans 1995, Spaans et al. 2007). If females are unable to compensate during spring fattening for the energetic shortfall experienced throughout autumn, then habitat changes in the winter staging areas could also translate into lower reproduction on the arctic breeding grounds. In recent years, Light-bellied Brent Geese have also started to feed on cereal fields in spring 
(Denny et al. 2004), as Zostera distribution has declined in spring staging areas (Frederiksen et al. 2003, Clausen et al. 2009). This has been followed by a decade of poor gosling productivity (on average $9.0 \%$ in the 2000 s, compared with $14.6 \%$ in the 1980 s, and $13.8 \%$ in the 1990s; updated from Clausen et al. 1998), and the ability to compensate during spring may therefore be limited. Any causal link between low autumn weights and effects on fitness requires further investigation, as conditions for spring fattening are also certainly deteriorating.

The East Atlantic Light-bellied Brent Goose has a small population that is covered by a suite of international habitat protection designations under the EU Birds and Habitats Directives, the Ramsar Convention and the African-Eurasian Waterbird Agreement (AEWA). Thus this population of Geese is probably among the best protected in national and international legislation, yet favourable management of its habitats is not secured. The results presented here call for dedicated management actions from the two main wintering range states, Denmark and the UK.

Seagrass and saltmarsh resources may be even more threatened in the future. Climate change scenarios predict higher nutrient loads which threaten to further increase problems with oxygen deficiency in inner coastal waters, thereby negatively affecting submerged seagrass beds (Short \& Neckles 1999). Moreover, rising sea levels may increasingly result in coastal squeeze and loss of alternative saltmarsh habitat (Hughes 2004). Collectively, these changes threaten to reduce substantially the area of suitable coastal habitats for herbivorous waterfowl in their temperate wintering areas. The outcome of these changes may be a landward shift in habitat use among many species, and many waterfowl species might face the challenge of adapting to a more terrestrial lifestyle in coming years. Even if this transition proves possible, further problems may then arise from rapidly changing land-use practices and conflicts with farmers.

We thank Tony Fox, Poul Hansen, Morten Frederiksen and three anonymous reviewers for very constructive comments on previous drafts of this paper.

\section{REFERENCES}

Adam, P. 2002. Saltmarshes in a time of change. Environ. Conserv. 29: 39-61.

Altmann, J. 1974. Observational study of behaviour: sampling methods. Behaviour 49: 227-267.
Bakken, G.S., Banta, M.R., Higginbotham, C.M. \& Lynott, A.J. 2006. It's just ducky to be clean: the water repellency and water penetration resistance of swimming Mallard Anas platyrhynchos ducklings. J. Avian Biol. 37: 561-571.

Bédard, J. \& Gauthier, G. 1986. Assessment of faecal output in geese. J. Appl. Ecol. 23: 77-90.

Brunckhorst, H. 1996. Ökologie und Energetik der Pfeifente (Anas Penelope L. 1758) im Schleswig-Holsteinischen Wattenmeer. Hamburg: Kovač.

Butler, P.J., Woakes, A.J. \& Bishop, C.M. 1998. Behaviour and physiology of Svalbard Barnacle Geese Branta leucopsis during their Autumn Migration. J. Avian Biol. 29: 536-545.

Chisholm, H. \& Spray, C. 2002. Habitat usage and field choice by Mute and Whooper Swans in the Tweed Valley, Scotland. Waterbirds 25 (Spec Publ 1) 17: 7-182.

Clausen, P. 1991. Light-bellied Brent Goose (Branta bernicla hrota): Phenology, distribution, habitat choice and feeding ecology in Denmark in the 1980s. MSc Thesis, Aarhus University, Denmark.

Clausen, P. 1998. Choosing between feeding on Zostera and salt marsh: Factors affecting habitat use by Brent Geese in spring. Norsk Polarinst. Skr. 200: 277-294.

Clausen, P. \& Percival, S.M. 1998. Changes in distribution and habitat use of Svalbard light-bellied Brent Geese Branta bernicla hrota, 1980-1995: Driven by Zostera availability? Norsk Polarinst. Skr. 200: 253-276.

Clausen, P., Madsen, J., Percival, S.M., O’Connor, D. \& Anderson, G.Q.A. 1998. Population development and changes in winter site use by the Svalbard Light-bellied Brent Goose, Branta bernicla hrota 1980-1994. Biol. Conserv. 4: 157-165.

Clausen, P., Madsen, J., Percival, S.M., Anderson, G.Q.A., Koffijberg, K., Mehlum, F. \& Vangeluwe, D. 1999. LightBellied Brent Goose Branta bernicla hrota: Svalbard. In Madsen, J., Cracknell, G. \& Fox, T. (eds) Goose Populations of the Western Palearctic. A Review of Status and Distribution: 312-327. Wageningen: Wetlands International Publ. No. 48.

Clausen, P., Frederiksen, M., Percival, S.M., Anderson, G. Q.A. \& Denny, M.J.H. 2001. Seasonal and annual survival of East-Atlantic Pale-Bellied Brent Geese Branta hrota assessed by capture-recapture analysis. Ardea 89 (Spec Iss) 10: 1-112.

Clausen, P., Meltofte, H. \& Holm, T.E. 2009. Vandfugle og bundvegetation i fjorde under global opvarmning har fuglene og vi et problem i Danmark. In Søgaard, B., Asferg, T. (eds) Arter 2007: 115-130. NOVANA. Danish National Environmental Research Institute, Ronde Aarhus University. Technical Report no. 713.

Demment, M.W. \& Van Soest, P.J. 1985. A nutritional explanation for body-size patterns of ruminant and nonruminant herbivores. Am. Nat. 125: 641-672.

Denny, M.J.H., Clausen, P., Percival, S.M., Anderson, G.Q.A., Koffijberg, K. \& Robinson, J.A. 2004. Light-Bellied Brent Goose Branta Bernicla Hrota (East Atlantic Population) in Svalbard, Greenland, Franz Josef Land, Norway, Denmark, the Netherlands and Britain 1960/61-2000/01. Waterbird Review Series. Slimbridge, UK: The Wildfowl \& Wetlands Trust/Joint Nature Conservation Committee.

Drent, R., Ebbinge, B. \& Weijand, B. 1978/79. Balancing the energy budgets of arctic-breeding geese throughout the 
annual cycle: a progress report. Verh. Ornithol. Ges. Bayern 23: 239-264.

Ebbinge, B.S. 1989. A multifactorial explanation for variation in breeding performance of Brent Geese Branta bernicla. Ibis 131: 196-204.

Ebbinge, B.S. \& Spaans, B. 1995. The importance of body reserves accumulated in spring staging areas in the temperate zone for breeding in Dark-bellied Brent Geese Branta b. bernicla in the high arctic. J. Avian Biol. 26: 105113.

Einarsen, A.S. 1965. Black Brant, Sea Goose of the Pacific Coast. Seattle: University of Washington Press.

Evans, P.R., Goss-Custard, J.D. \& Hale, W.G. 1984. Coastal Waders and Wildfowl in Winter. Cambridge: Cambridge University Press.

Fælled, C.C. 2011. Impacts of habitat loss on a herbivorous waterbird guild in the Danish estuary Mariager Fjord. MSc Thesis, Aarhus University, Denmark.

Fog, M. 1967. An Investigation on the Brent Goose (Branta bernicla) in Denmark. Dan. Rev. Game Biol. 5: 1-40.

Fog, M.. 1972. Status for Knortegåsen (Branta Bernicla). Kalø: Game Biology Station.

Fox, A.D., Ebbinge, B.S., Mitchell, C., Heinicke, T.A., Colhoun, K., Clausen, P., Dereliev, S., Farago, S., Koffijberg, K., Kruckenberg, H., Loonen, M.J.J.E., Madsen, J., Mooij, J., Musil, P., Nilsson, L., Pihl, S. \& Van der Jeugd, H. 2010. Current estimates of goose population sizes in western Europe, a gap analysis and an assessment of trends. Ornis Svec. 20: 115-127.

Frederiksen, R., Nygaard, K., Pedersen, J. \& Spanggaard, G. 2003. Bundvegetationen i Limfjorden 2002. Aabyhøj: Bio/ consult AS.

Ganter, B. 2000. Seagrass (Zostera spp.) as food for Brent Geese (Branta bernicla): an overview. Helgoland Mar. Res. 54: 63-70.

Hughes, R.G. 2004. Climate change and loss of saltmarshes: consequences for birds. Ibis 146: 21-28.

Inger, R., Gudmundsson, G.A., Ruxton, G.D., Newton, J., Colhoun, K., Auhage, S. \& Bearhop, S. 2008. Habitat utilization during staging affects body condition in a long distance migrant, Branta bernicla hrota: potential impacts on fitness? J. Avian Biol. 39: 704-708.

Irving, L., Krog, H. \& Monson, M. 1955. The metabolism of some Alaskan animals in winter and summer. Physiol. Zool. 28: 173-185.

Kamil, A.C., Krebs, J.R. \& Pulliam, H.R. (eds) 1987. Foraging Behavior. New York: Plenum.

Kilgore, D.L. \& Schmidt-Nielsen, K. 1975. Heat loss from ducks' feet immersed in cold water. Condor 77: 475-478.

Ladin, Z.S., Castelli, P.M., McWilliams, S.R. \& Williams, C.K. 2011. Time energy budgets and food use of Atlantic Brant across their wintering range. J. Wildl. Manage. 75: 273-282.

Lane, S.J. \& Hassall, M. 1996. Nocturnal feeding by Darkbellied Brent Geese Branta bernicla bernicla. Ibis 138: 291297.

Lasiewski, R.C. \& Dawson, W.R. 1967. A re-examination of the relation between standard metabolic rate and body weight in birds. Condor 69: 13-23.

Lefebvre, E.A. \& Raveling, D.G. 1967. Distribution of Canada Geese in winter as related to heat loss at varying environmental temperatures. J. Wildl. Manage. 31: 538-546.
Mathers, R.G. \& Montgomery, W.I. 1997. Quality of food consumed by overwintering Pale-bellied Brent Geese Branta bernicla hrota and Wigeon Anas penelope. Biol. Environ. 97b: 81-89.

Naturstyrelsen. 2011. Natura 2000-Plan 2010-2015. Ålborg Bugt, Randers Fjord og Mariager Fjord, Natura 2000Område nr. 14. Danish Ministry of the Environment, Aalborg, Danish Nature Agency.

Nolet, B.A., Bevan, R.M., Klaassen, M., Langevoord, O. \& Van der Heijden, Y.G.J.T. 2002. Habitat switching by Bewick's swans: maximization of average long-term energy gain? J. Anim. Ecol. 71: 979-993.

Owen, M. 1975. An assessment of fecal analysis technique in waterfowl feeding studies. J. Wildl. Manage. 39: 271-279.

Owen, M., Wells, R.L. \& Black, J.M. 1992. Energy budgets of wintering Barnacle Geese: the effects of declining food resources. Ornis Scand. 23: 451-458.

Persson, H. 1989. Food selection, movements and energy budgets of staging and wintering geese on South Swedish farmland. PhD Thesis, University of Lund, Sweden.

Prop, J. \& Black, J.M. 1998. Food intake, body reserves and reproductive success of barnacle geese Branta leucopsis staging in different habitats. Norsk Polarinst. Skr. 200: 175 193.

Prop, J. \& Vulink, T. 1992. Digestion by Barnacle Geese in the annual cycle: the interplay between retention time and food quality. Funct. Ecol. 6: 180-189.

Pyke, G.H., Pulliam, H.R. \& Charnov, E.L. 1977. Optimal foraging - selective review of theory and tests. Q. Rev. Biol. 52: $137-154$.

Rowcliffe, J.M., Watkinson, A.R., Sutherland, W.J. \& Vickery, J.A. 1995. Cyclic winter grazing patterns in Brent Geese and the regrowth of salt-marsh grass. Func. Ecol. 9: 931-941.

Salomonsen, F. 1958. The present status of the Brent Goose (Branta bernicla (L.)) in Western Europe. Vid. Medd. Dan. Nat. Hist. Foren. 120: 43-80.

Short, F.T. \& Neckles, H.A. 1999. The effects of global climate change on seagrasses. Aquat. Bot. 63: 169-196.

Spaans, B. \& Postma, P. 2001. Inland pastures are an appropriate alternative for salt-marshes as a feeding area for spring-fattening Dark-Bellied Brent Geese Branta bernicla. Ardea 89: 427-440.

Spaans, B., van't Hoff, K., van der Veer, W. \& Ebbinge, B.S. 2007. The significance of female body stores for egg laying and incubation in Dark-Bellied Brent Geese Branta bernicla bernicla. Ardea 95: 3-15.

Stahl, J., Veeneklaas, R.M., van der Graff, S. J., Loonen, M. J.J.E. \& Drent, R.H. 2001. Conversion factors for energetic expenditure of actively foraging brent and barnacle geese obtained by non-invasive heart rate telemetry. In Stahl, J. (ed.) Limits to the Co-Occurrence of Avian Herbivores: 95119. PhD Thesis, University of Groningen, The Netherlands.

Stephenson, R. \& Andrews, C.A. 1997. The effect of water surface tension on feather wettability in aquatic birds. Can. J. Zool. 75: 288-294.

Stock, M. \& Hofeditz, F. 1997. Grenzen der Kompensation: Energiebudgets von Ringelgänsen (Branta $b$. bernicla) die Wirkung von Störreizen. J. Ornithol. 138: 387-411.

Tinkler, E., Montgomery, W.I. \& Elwood, R.W. 2009. Foraging ecology, fluctuating food availability and energetics of wintering Brent Geese. J. Zool. 278: 313-323. 
Tubbs, C.R. \& Tubbs, J.M. 1982. Brent Geese Branta bernicla bernicla and their food in the Solent, Southern England. Biol. Conserv. 23: 33-54.

Valentine, J.F. \& Duffy, J.E. 2006. The central role of grazing in seagrass ecology. In Larkum, A.W.D., Orth, R.J., Duarte, C.M. (eds) Seagrasses: Biology, Ecology and Conservation: 463-501. Dordrecht: Springer.

Van Sant, M.J. \& Bakken, G.S. 2006. Thermoregulation on the air-water interface II: Foot conductance, activity metabolism and a two-dimensional heat transfer model. J. Therm. Biol. 31: 491-500.

Ward, D.H. 1983. The Relationship of Two Seagrasses: Zostera marina and Ruppia maritima to the Black Brant Branta bernicla nigricans, San Ignacio Lagoon, Baja California, Mexico. MSc Thesis, University of Oregon, Eugene, OR.

Ward, D.H., Reed, A., Sedinger, J.S., Black, J.M., Derksen, D.V. \& Castelli, P.M. 2005. North American Brant: effects of changes in habitat and climate on population dynamics. Glob. Change Biol. 11: 869-880.
Waycott, M., Duarte, C.M., Carruthers, T.J.B., Orth, R.J., Dennison, W.C., Olyarnik, S., Calladine, A., Fourqurean, J. W., Heck, K.L., Hughes, A.R., Kendrick, G.A., Kenworthy, W.J., Short, F.T. \& Williams, S.L. 2009. Accelerating loss of seagrasses across the globe threatens coastal ecosystems. Proc. Natl Acad. Sci. USA 106: 12377-12381.

Wooley, J.B. \& Owen, R.B. 1978. Energy costs of activity and daily energy expenditure in the black duck. J. Wildl. Manage. 42: 739-745.

Zaldívar, J.M., Bacelar, F.S., Dueri, S., Marinov, D., Viaroli, P. \& Hernández-García, E. 2009. Modelling approach to regime shifts of primary production in shallow coastal ecosystems. Ecol. Model. 220: 3100-3110.

Received 5 March 2012; revision accepted 7 July 2012. Associate Editor: Morten Frederiksen. 